\title{
DAILY COMMUTING - SIMILARITIES AND DIFFERENCES BETWEEN SERBIA AND SLOVENIA
}

\section{DNEVNE MIGRACIJE - PODOBNOSTI IN RAZLIKE MED SRBIJO IN SLOVENIJO}

Vesna Lukić, Branka Tošić

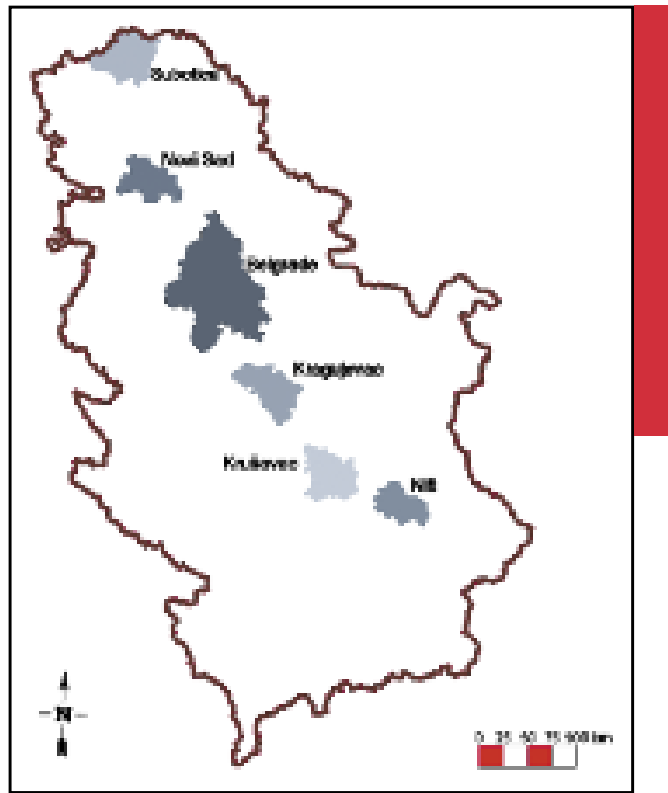

Municipalities with greatest employment attraction in Serbia. Občine z najvišjo zaposlitveno privlačnostjo v Srbiji. 


\title{
Daily commuting - similarities and differences between Serbia and Slovenia
}

DOI: $10.3986 /$ AGS51205

UDC: $911.37: 314.15(497.1: 497.4)$

COBISS: 1.01

\begin{abstract}
As one form of population mobility, daily commuting represents very complex phenomenon of the spatial separation of the place of work and the place of residence of the part of employed population. The paper deals with changes in scope, directions and structure of commuting flows in Serbia, as well as the interdependence of commuting with other demographic and socio-economic development processes. The comparison was made between the basic characteristics of commuting in Serbia and Slovenia and their catchment areas of employment attraction. The differences in methodology used in the census questionnaires referring to commuters in the last population censuses of Serbia and Slovenia in year 2002 were also discussed.
\end{abstract}

KEY WORDS: geography, migration, commuting, workers, regional disparities, suburbanization, Serbia, Slovenia

The article was submitted for publication on July 13, 2011.

\section{ADDRESSES:}

Vesna Lukić, Ph. D.

Demographic Research Centre

Institute of Social Sciences

Kraljice Natalije 45, 11000 Belgrade, Serbia

E-mail: vlukic@idn.org.rs

\section{Branka Tošić, Ph. D.}

Faculty of Geography, University of Belgrade Studentski trg 3/III, 11000 Belgrade, Serbia

E-mail: brankat@ikomline.net

\section{Contents}

1 Introduction 321

2 Methodology 321

3 Characteristics of Commuting in Serbia Situation, Trends and Challenges $\quad 322$

4 Daily commuting - Similarities and Differences between Serbia and Slovenia $\quad 323$

5 Conclusion 328

6 Acknowledgement 328

7 References 328 


\section{Introduction}

Daily commuting represents the demographic, socio-economic and cultural links between the places of residence and places of work of commuters, with numerous causes and effects in both areas. This specific form of the spatial mobility of population is interrelated with demographic, socio-economic, transport, and settlement development, as well as the development of the labour and real estate markets in the settlement of residence and settlement of employment of commuters. As Bole stated, we can speak about a typical geographical phenomenon that has cause-effect relationship with other spatial factors (Bole 2004, 28). As the indicator of strength and borders of the functional attractiveness of settlements, the commuting flows are connected with the limitations and possibilities in regards to the place of residence and place of work, and so the main directions of commuting of certain area can also change by the time. Establishing the number of commuters (e.g. users of services and infrastructure of the settlement in the place of work (i.e. the so-called servicing population) in relation to the population who live in certain place of residence as well as research of changes of directions, scope and qualitative characteristics of job commuters is significant from the viewpoint of transport and other infrastructure, protection of the environment, as well as formulation of corresponding demographic and economic policies.

A precondition for commuting to occur has been the heterogeneity of population and socio-economic conditions within the spatial and temporal distance which is favourable for its development. There will not be incentive for intercity commuting if some kinds of heterogeneity are not introduced (Sun 1980, p.98). As the socio-economic, demographic and other differences are larger between the starting and targeted settlements and population that inhabits them, the larger is the probability of commuting and other forms of spatial mobility to appear. Which of the factors will be of the prevailing influence on commuting depends on the characteristics of an individual commuter, as well as particular settlement area.

\section{Methodology}

Apart from advantages that the census data have for studying the commuting patterns, as well as the fact that data were not just given for certain location, as it is the case with polling research, the published results of the population censuses, given by the official institutions in Serbia, are limited for scientific researches. The published data on commuters enable the assessment of the scope and directions of the flowing trends of labour of given administrative territorial unit but only offered data on outflows of daily commuters on the level of municipalities. Therefore, it is impossible to come to the knowledge on the total functional effect of certain urban area.

In order to obtain as much larger spectrum of information on the characteristics of commuters for the research, the results of special data processing of the 2002 population census were used as a data source in this paper (e.g. the main focus of the special census data processing is on individual commuters, not on certain social groups). The tables of places of residences and places of work were crossed together with certain demographic and socio-economic characteristics of commuters which enabled the perspective of paths while establishing the dominant directions of commuting of different population groups. The cross-tabulation of data on commuting towards/from settlements enabled the study of the functional effect of individual settlements and defining the functional areas of municipalities and corresponding daily urban systems.

Both in Serbia and Slovenia, a commuter is defined as a person that has a place of work in a different settlement area (defined by the statistical spatial unit) than a place of residence (Statistical Office of the Republic of Serbia, 2002; Internet 5). Nevertheless, differences in regard of the possibilities of the study of commuting in Serbia and Slovenia, concerning the census data, are in direct connection with the questions in the census questionnaires referring to commuters. The 2002 census questionnaire in the Republic of Serbia contains only a question about the frequency of returning of workers from places of work to places of residence (i.e. the offered categories of answers were: everyday, once a week and rarely) and the category of commuters is selected on the basis of this question. In contrast to the 2002 census questionnaire in Serbia, the 2002 census questionnaire in Slovenia contains several questions, which enable the selection of the category of population who work at home, as well as questions on the mode of transport to work and time in minutes spent for journey to work in one direction (Internet 5). The question on 
the mode of transport to work for commuters will also be introduced in the 2011 census questionnaire in Serbia in accordance with the recommendations of CES (Conference of European Statistics) for the 2011 censuses of population, households and housing. It will enable the comparativeness of data with other countries, and Slovenia is among them, despite the fact that Slovenia will undertake for the first time the comprehensive data registry of population instead of traditional census methods.

The changes in scope, directions and flows of commuting in Serbia are discussed in this paper, as well as their causes and effects. Based on the inter-municipal commuting of workers, basic characteristics of commuting in Serbia and Slovenia (situation, trends and challenges) and their areas of employment attraction are compared.

\section{Characteristics of commuting in Serbia - situation, trends and challenges}

Due to decrease in demographic potentials particularly in rural settlements - »... even in the case of substantial improvement of total fertility rate, no positive demographic effects should be experienced ... « (Nikitović and Lukić 2010,106 ). The extent of rural-to-urban migrations gradually decreases, while the extent of migrations between the smaller and larger urban centres has increased together with the total number of commuters. In 1981, 514775 commuters travelled to work daily in Serbia, of which $26 \%$ were inter-municipal commuters. The 2002 census data showed 565054 commuters, of which 194345 (34\%) were inter-municipal commuters (Statistical Office of the Republic of Serbia, 2004).

Disproportions in the population density and number of inhabitants between the regions, as well as economic and social polarisation have mostly influenced the scope and directions of commuting flows in Serbia. Moreover, the current economic reforms, the process of deindustrialisation and privatisation of larger enterprises have been significant for the changes in the commuting flows (directions and structure). From year 2001, the transition of the labour market developed in two main directions in Serbia: the first one was the reduction in the total number of employed as well as low employment rate of the population, while the second one was the continuing rate of high unemployment (Matković et al. 2010). The increase in the number of commuters in Serbia is one of the ways how the population is adapting and overcoming the problems of unemployment and lack of adequate jobs in the local milieu, while at the same time, maintaining of commuting as the form of mobility that prevents further concentrating of population in urban centres. »The fact that they serve as the residence of commuters enables small towns to maintain the inflow of income as almost every small factory or a shop would bring them« (Parr 1987, p.225).

The transitional processes in Serbia in the first decade of the $21^{\text {st }}$ century have had significant effects on decline of income which was caused by reduced or completely absent investments, gradual economic »collapse « of enterprises and unresolved legal property rights in the process of privatization, dilapidated infrastructure, etc. The urban centres in which industry was a dominant employment sector (i.e. production of transportation vehicles, textile and metal industry) were most affected by these processes. Thus, from the previous »industrial giants «, some municipalities were found to be in the category of underdeveloped areas and their revenues decreased considerably (Tošić et al. 2009; Miletić et al. 2009). Large number of redundant workers considerably increased the share of unemployment in the first decade of the 21 century, which is increasing by average annual rate of $1.6 \%$, with high share of long-term unemployed, young and unskilled persons.

The scope of commuting is associated with the limitations and possibilities regarding the places of residence and places of work i.e. the situation on the labour and real estate markets. Violated economic relations in undeveloped areas resulted in the increase in the extent of commuting. Most municipalities in Serbia which are the place of residence (starting point) of larger number of commuters towards other municipalities as places of work have mainly large number of unemployed and low values of gross national income per capita. Unrealistically high prices of real estates in larger urban centres also influence the commuting flows in Serbia making the obstacle to migration, while relatively low transportation prices are also important. The researches in Serbia have shown in the example of the town of Pančevo $(21 \mathrm{~km}$ from Belgrade) in the province of Vojvodina that $93.8 \%$ of commuters live in residences that are in the ownership of their families (Lukić 2008). That is also the confirmation of other authors' knowledge (Hanson 
and Pratt 1998) that the owners of housing more often choose this form of daily mobility in relation to residential migration.

Concerning the commuting trend in Serbia, gradual increase in the share of women in the employed population is noticeable, as well as in the structure of daily commuters according to gender, although apart from these changes men have still been the predominant among workers. The structure of employed population, according to the sector of employment, has changed due to strengthening of the service sector in the structure of the national economy. Therefore, the share of commuters employed in the primary and secondary sector decreases gradually, while the increase in the share of commuters employed in service sector is observed.

The commuting trend in Serbia will depend on further changes in biological and socio-economic structure of labour force. Better transport connections and the improvement on the quality of transport infrastructure are important spatial factors of influence which will also contribute to the formation of new directions of commuting flows in Serbia, considering that the increase in the number of commuters on longer relations has been the general trend. The trend of the return of population to rural settlements is particularly noticeable in England and the USA that influenced the increase in the number of inhabitants in these settlements. It is considered that people themselves decide to bear the load of additional travelling to work, in change for quality of life in villages in contrast to urban life. In that case, the life style prevails in relation to economic factors considering that the path of commuting mainly becomes longer in this case (Renkow and Hoower 2000,267). In Serbia, there is still no suburbanisation of wealthier social classes that commute daily to larger urban centres. Population still mainly moves to towns (due to larger number of workplaces in towns). Most migrants move to surrounding suburban settlements due to lower real estate prices in these settlements while commute daily to larger near-by towns. However commuting of workers in Serbia is not driven by the search »for a greener environment « but due to - either a low number of work places in the settlements of residence mainly caused by uneven economic development, as well as concentration of functions in larger urban centres, or higher unemployment rate due to job losses during transitional processes in Serbian economy.

\section{Daily commuting - similarities and differences in Serbia and Slovenia}

Observing similarities and differences is a fundamental cognitive process (Gentner and Markman 1994). One of the similarities between Serbia and Slovenia, concerning the commuting process is that economic factors here play significant role. The number of work places in municipality is strongly related with daily commuting of workers in both countries. Many rural settlements, studied by Topole et al., showed surplus of the economically active population over the number of jobs which brought the increased in the levels of commuting by residents (Topole et al. 2006).

In Serbia $22 \%$ of economically active population was involved in commuting in year 2002, while $54 \%$ in Slovenia (Statistical Office of the Republic of Serbia, 2002; Internet 1). Although the increase is noticeable in the number of commuters who travel daily to another municipality, in Serbia commuting is most intensive within the same municipality, while in Slovenia inter-municipal commuters are prevailing due to smaller size of municipalities.

The map (see Figure 1) shows all municipalities of Serbia (44 of total 161) where at least one tenth of workers $(10 \%)$ commuted to another municipality in year 2002. The most noticeable inter-municipal commuting of workers in year 2002 can be observed in the municipalities of Sremski Karlovci, Niška Banja and Doljevac next to macro-regional centres (Novi Sad - 299294 and Niš - 250518 inhabitants), as well as suburban Belgrade municipalities out of the inner city (urban settlement of Belgrade): Barajevo, Grocka and Sopot. In the group of ten municipalities in Serbia, from which more than one third of workers commuted daily to another municipality in year 2002, four municipalities (Grocka, Sremski Karlovci, Doljevac and Merošina) had larger number of unemployed than employed population (Lukić 2006, 146).

Figure 1: Proportion of inter-municipal commuters in selected municipalities of Serbia. $>$ p. 324

Figure 2: Proportion of inter-municipal commuters in municipalities of Slovenia. $>$ p. 325 


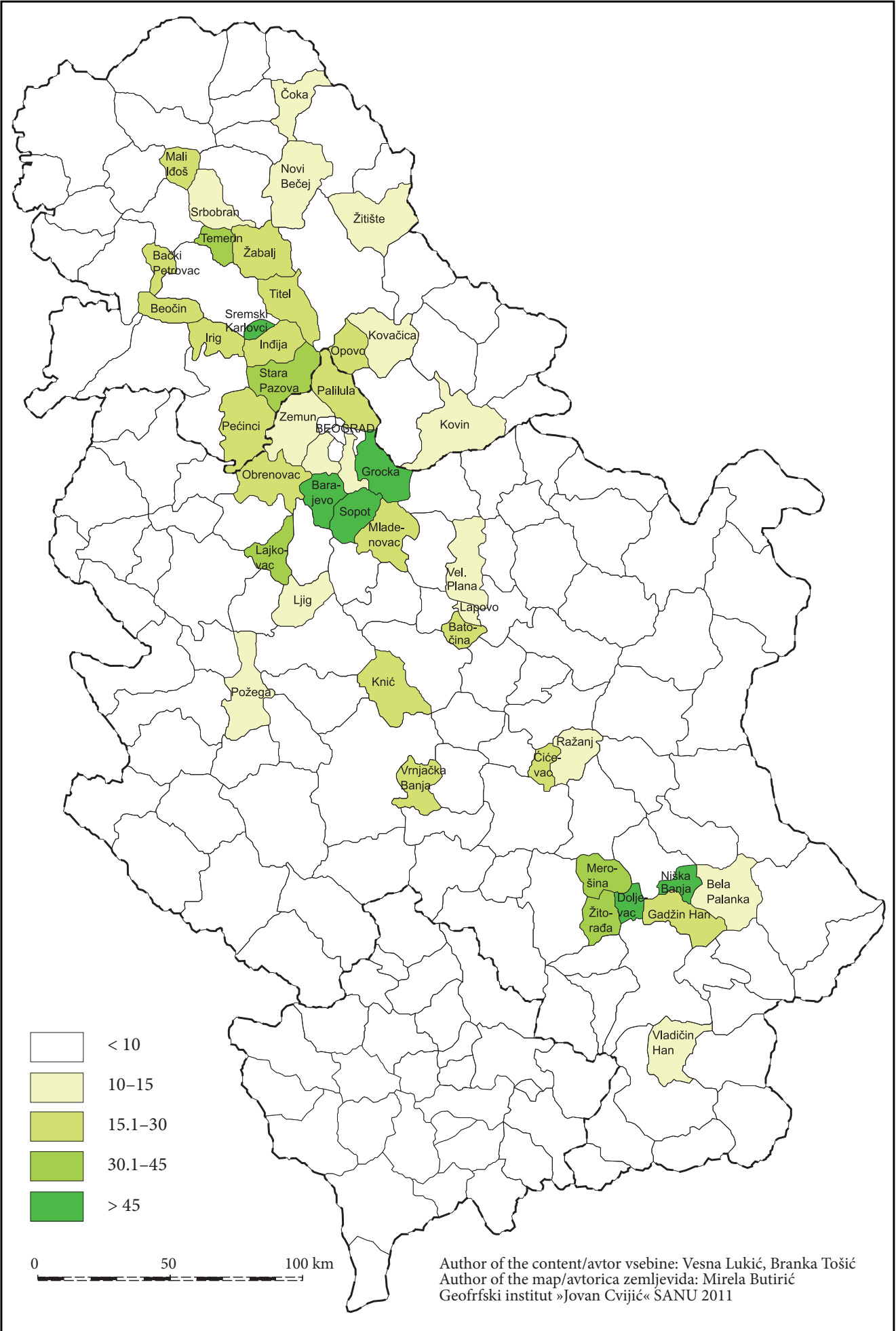




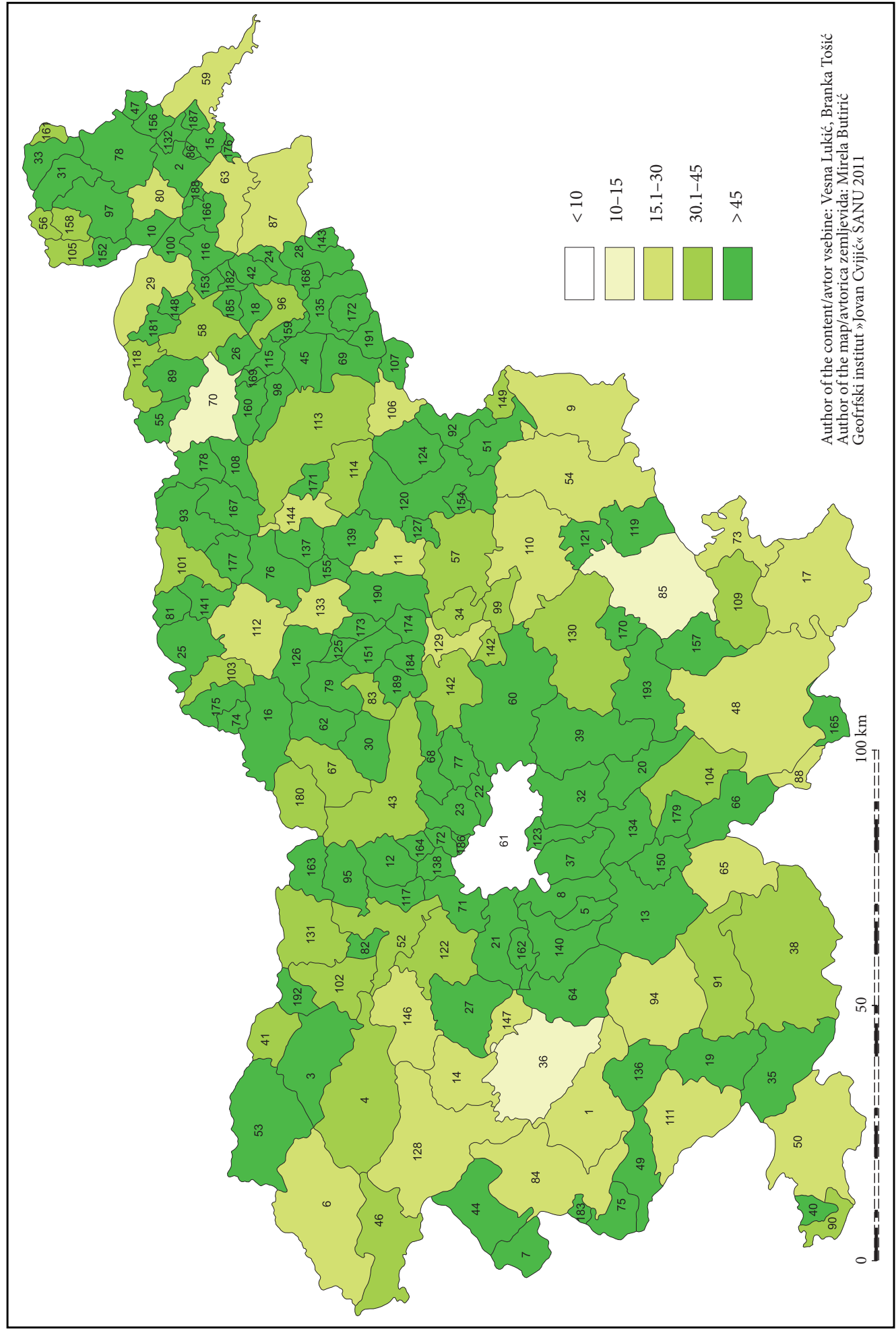


In comparison to Serbia, in all municipalities in Slovenia, with the exception of Ljubljana (see Figure 2) more than $10 \%$ of workers commuted to another municipality in year 2002 . In Serbia there are only 10 municipalities (out of 161 municipalities in year 2002) with more than $35 \%$ of workers who commuted to another municipality, while in Slovenia this number was 152 (out of 192 municipalities in year 2002) (Internet 1, Internet 3).

In the cross-border municipalities of Slovenia, there is a phenomenon of cross-border daily mobility that is not the case in Serbia. The reasons for daily commuting over the borders in Slovenia includes the inadequate number and structure of jobs in local communities in Slovenia, income differences, especially between Slovenia, Austria and Italy, additional sources of income, personal interests of working abroad, availability and qualifications of population (Zupančič 2000). External daily mobility is estimated to be much higher than stated by the official data (i.e. 4,500, unofficially 13,000 daily commuters) (Social overview ... 2008).

Qualitative differences of the labour force between the municipality as the place of work and the municipality as the place of residence and the inconsistency between the number of educated population and the level of their qualification with the needs of the economy and society reflect directly the scope and flows of commuting in Serbia. Concerning education, the positive relationship of commuting with secondary school education and negative relationship with college and university education is noticeable in Slovenia (Bole 2004). The reason may be the concentration of functions in larger urban centres. Final 2002 census results on education level of the whole population of Serbia show that among population aged 15 years and over, $41.1 \%$ have secondary education, $23.9 \%$ have primary education and $11 \%$ are highly educated (Statistical Office of the Republic of Serbia, 2003). In the structure of commuters in Serbia, workers with the secondary school education have the predominance of $59.8 \%$, whereas only $13.4 \%$ are highly skilled workers (Statistical Office of the Republic of Serbia, 2007). Two-thirds of these commuters travel between settlements within the borders of the same municipality. Observing only commuters with university education, even $82.3 \%$ of the total number of commuters with university education is involved into the inter-municipal commuting (Lukić and Tošić 2009). There is no census data about commuting distance in Serbia. However, considering that the Serbian municipalities have a rather large average area $\left(557 \mathrm{~km}^{2}\right)$ with 34 settlements average, as well as two-thirds of the commuters travel daily between two settlements within the borders of the same municipality, we can confirm that commuting distances are longer for inter-municipal commuters, i.e. those who are mainly highly skilled ones.

Even though there are not census data that would indicate the modal split of commuters for Serbia as a whole, the results of polling research, according to Bjeljac (1992) and Petrović (2001), showed that the largest number of commuters use public transport and bus as dominant means of transport. Moreover, there are cases when commuters combine different means of transport. The selection of public transport, as the most frequent way of travelling to work of commuters in Serbia has been the consequence of high costs of transport by their personal vehicles that most commuters cannot bear financially by themselves. In contrast to that, most workers in Slovenia travel to work by car (Gabrovec and Bole 2009).

There are 26 regional centres in Serbia (Belgrade, Niš, Novi Sad, Čačak, Jagodina, Kikinda, Kragujevac, Kraljevo, Kruševac, Leskovac, Loznica, Novi Pazar, Pančevo, Pirot, Požarevac, Šabac, Smederevo, Sombor,

Table 1: Selected municipalities in Serbia and their employment attraction.

\begin{tabular}{lccccccc}
\hline \multirow{2}{*}{ Municipalities } & Number of & \multicolumn{5}{c}{ Number of municipalities with commuters as proportion of total workforce } \\
\cline { 3 - 7 } & work places & below 1\% & $1-10 \%$ & $10-20 \%$ & $20-40 \%$ & $40-60 \%$ & 0ver 60\% \\
\hline Belgrade & 558739 & 57 & 44 & 6 & 5 & 1 & 7 \\
Kragujevac & 63102 & 46 & 8 & 2 & 1 & 2 & 1 \\
Kruševac & 46954 & 48 & 6 & 2 & 2 & 1 & 2 \\
Niš & 90057 & 43 & 10 & 3 & 3 & 3 & 7 \\
Novi Sad & 122338 & 59 & 23 & 5 & 0 & 1 & 2 \\
Užice & 32139 & 27 & 4 & 3 & 1 & 1 & 1 \\
Subotica & 54514 & 41 & 9 & 1 & & 2 & 1 \\
\hline
\end{tabular}

Source: Statistical Office of the Republic of Serbia, 2007; own calculations. 
Sremska Mitrovica, Subotica, Užice, Valjevo, Vranje, Vršac, Zaječar, Zrenjanin) selected for the needs of investigating the employment attraction of municipalities in Serbia, and their comparison with the employment attraction of municipalities in Slovenia (see Bole, 2004) according to selected methodology. They are defined according to (the draft of) the Spatial Plan of the Republic of Serbia 2010-2014-2021 (Internet 4). Municipalities which simultaneously attract workers and are also significant source of commuting flows towards other municipalities are excluded from this group, as well as municipalities which attract workers from small number of municipalities. The City Municipality of Belgrade has by far greatest employment attraction, while town of Novi Sad in the province of Vojvodina is the second, and the town of Niš in south-east Serbia is the third largest employment centre in Serbia (see Table 1).

The researches of employment attraction of municipalities in Serbia and Slovenia show that the capital cities in both countries have by far the greatest employment attraction, offering the most work places relative to both number and diversity of jobs. The huge functional influence of the capital city of Slovenia, i.e. Ljubljana, is evident at the NUTS 2 level. In the case of three functional regions of international importance, functional region of Ljubljana cover $78 \%$ of the country (Drobne et al. 2010, 301). Similar situation is observed in Spain and Italy (as in and other European countries) where the most dominant directions of commuting are from regions surrounding the capital of the province or district towards the capital cities themselves (Artis et al. 2000; Cristaldi 2005). Data on employment attraction of municipalities in Serbia confirm the significance of the urban centres at the Danube-Morava corridor as the main axis of the development of Serbia (Nikitović and Lukić 2003). Moreover, there is no larger centre of employment of more significant attraction in Eastern Serbia that is a traditional emigration area.

The ratio between the number of jobs and the number of persons in paid employment and self-employed persons in municipality shows surplus or lack of jobs in the municipality. If the number of jobs in a municipality is at least $16 \%$ greater than the number of people living in it, such municipality is very labour-oriented (see Internet 2). In 2002, most municipalities in Serbia were among residential municipalities, while some Belgrade municipalities were among very labour oriented ones, as well as macro-regional centres of Kragujevac, Novi Sad and Niš. It should bear in mind that these categories are subjected to changes in accordance with the changes of socio-economic conditions in municipalities of residence and employment of commuters. For example, towns of Koper, Nova Gorica and Kranj in Slovenia were in year 2005 among very labour-oriented municipalities but in year 2006 they felt into category of moderately labour-oriented municipalities (see Internet 2).

If data for values of daily migration index (changed its name into labour migration index in Slovenia after 2007) are compared, it can be seen that most municipalities are among very residential ones in Serbia, whereas they are in the category of moderately residential ones in Slovenia. It should also bear in mind the fact that the results are not completely comparable due to different time periods from which the available data were recorded.

The average Slovenian commuter is a man, has a secondary education, lives between fifteen and thirty minutes from the place of employment and drives to work alone in an automobile (Bole 2004; Bole 2010; Kozina 2010; Internet 2) to another municipality. The average Serbian commuter is also a man, has a secondary education, while he uses public transport to get to the place of work in the same municipality.

Table 2: Daily migration index by municipalities in Serbia (2002) and Slovenia (2006).

\begin{tabular}{lcccc}
\hline & $\begin{array}{c}\text { Number of municipalities } \\
\text { in Serbia }\end{array}$ & $\%$ & $\begin{array}{c}\text { Number of municipalities } \\
\text { in Slovenia }\end{array}$ & $\%$ \\
\hline very residential (below 35,9) & 66 & 40.9 & 37 & 19.2 \\
predominantly residential $(36-55,9)$ & 23 & 14.3 & 43 & 22.2 \\
moderately residential $(56-75,9)$ & 17 & 10.5 & 48 & 24.9 \\
weakly residential $(76-95,9)$ & 6 & 3.7 & 32 & 16.6 \\
moderately labour oriented (96-115,9) & 13 & 8.1 & 20 & 10.4 \\
very labour oriented (116 or more) & 36 & 22.4 & 13 & 6.7 \\
Total & 161 & 100 & 193 & 100 \\
\hline
\end{tabular}

Source: Statistical Office of the Republic of Serbia, 2007; Internet 2; own calculations. 


\section{Conclusion}

Numerous effects of commuting require the continuing research on changes of directions and scopes of commuting flows and also qualitative characteristics of job commuters as well as the determinants of these changes. Everyday travelling of the part of population from one settlement to another has the positive effect on decrease in investing in housing and local infrastructure of the settlements of employment (mostly towns). On the other hand, the overloading of main transport routes on the commuting flows can cause the necessity for more frequent and unplanned larger investments in transport network and public transport.

The characteristics of daily mobility of workers have been different depending on the characteristics of geographical areas. The study of the employment attraction of municipalities and calculated values of daily migration index in Serbia and Slovenia has shown that the capital cities in both countries have by far the greatest employment attraction. In Serbia the dominant functional attraction of the capital city of Belgrade is more noticeable in relation to other urban centres, taking in consideration regional polarisation and concentration of population and functions in few larger urban centres.

The dominant directions of commuting flows, as well as structural characteristics and the way of transport of commuters in Serbia and Slovenia show certain similarities but also differences. The reasons for these differences in daily commuting between Serbia and Slovenia can be found in different sizes of the territories between this two countries, the specificities of the settlement networks, characteristics and the quality of transport infrastructure, as well as the overall development and standard of living in Serbia and Slovenia. In Slovenia employed population is more daily commuting to work by car and between municipalities, taking in consideration also the smaller size of municipalities in Slovenia in comparison to Serbia. It would be very interesting for further research to investigate and compare other characteristics of commuters in these and neighbouring countries, as well as their changes over time. This will certainly be contributed by additional questions associated with commuters that are planned by the next population census in Serbia in year 2011.

\section{Acknowledgement}

This study resulted from the project funded by the Ministry of Education and Science of Serbia (No. 47006).

\section{References}

Artis, M., Romani, J., Surinach, J. 2000: Determinants of Individual Commuting in Catalonia, 1986-1991: Theory and Empirical Evidence. Urban Studies 37-8. London. DOI: 10.1080/00420980020080191

Bjeljac, Ž. 1992: Strukture dnevnih migranata u opštini Beočin. Zbornik Matice Srpske za društvene nauke 92-93. Novi Sad.

Bole, D. 2004: Daily mobility of workers in Slovenia. Acta geographica Slovenica 44-1. Ljubljana. DOI: 10.3986/AGS44102

Cristaldi, F. 2005: Commuting and Gender in Italy: A Methodological Issue. The Professional Geographer 57-2. London. DOI: 10.1111/j.0033-0124.2005.00477.x

Drobne, S., Konjar, M., Lisec, A., Pichler Milanović, N., Zavodnik Lamovšek A. 2010: Functional Regions Defined by Urban Centres of (Inter)National Importance - The Case of Slovenia. Proceedings Real Corp. Vienna. http://www.corp.at (18.12.2010).

Gabrovec, M., Bole, D. 2009: Dnevna mobilnost v Sloveniji. Georitem 11. Ljubljana.

Gentner, D., Markman, A. B. 1994. Structural alingment in comparison: No difference without similarity. Psychological Science 5-3. Washington.

Hanson, S., Pratt, G. 1988: Reconceptualizing the links between home and work in urban geography. Economic Geography 64-4. Worcester. 
Labour force by status in employment, municipalities Slovenia. Statistical Office of the Republic of Slovenia Census of Population, Households and Housing. 2002.

Labor migrations Slovenia 2006. Statistical office of the Republic of Slovenia. Internet 1: http://www.stat.si/ eng/novica_prikazi.aspx?id=1280 (31.05.2010);

Internet 2: http://www.stat.si/doc/metod_pojasnila/07-234-mp.htm (16.08.2010).

Lukić, V. 2006: Dnevne migracije aktivnog stanovništva u Srbiji. Glasnik Srpskog geografskog društva 86-1. Beograd.

Lukić, V. 2008: Konvergentne i divergentne dnevne migracije stanovništva Pančeva. Doktorska disertacija. Geografski fakultet Univerziteta u Beogradu. Beograd.

Lukić, V., Tošić, B. 2009: Nivo kvalifikovanosti radnika kao faktor odvijanja dnevnih migracija u Srbiji. Glasnik srpskog geografskog društva 89-2. Beograd.

Matković, G., Mijatović, B., Petrović, M. 2010: Uticaj krize na tržište radne snage i životni standard u Srbiji. Beograd.

Miletić, R., Todorović, M., Miljanović, D. 2009: Pristup nerazvijenim područjima u regionalnom razvoju Srbije. Zbornik radova Geografskog instituta »Jovan Cvijić« SANU 59-2. Beograd.

Nikitović, V., Lukić, V. 2010: Could refugees have a significant impact on the future demographic change of Serbia? International Migration 48-1. London. DOI:10.1111/j.1468-2435.2009.00519.x

Nikitović, V., Lukić, V. 2003: Comparative analysis of basic aggregate indicators of Danube-Morava corridor municipalities' demographic change, Zbornik radova Geografskog instituta »Jovan Cvijić« SANU 52. Beograd.

Parr, J. B. 1987: Interaction in an urban system: aspects of trade and commuting, Economic Geography 63-3. Worcester.

Persons in employment - daily commuters by municipality of residence and municipality of place of work, municipalities Slovenia. Statistical Office of the Republic of Slovenia Census of Population, Households and Housing. 2002.

Internet 3: http://www.stat.si/pxweb/Dialog/varval.asp?ma=OBC-21E\&ti=21\%2E+Persons+in+employment+\%2D+daily+commuters+by+municipality+of+residence+and+municipality + of ++ place + of + work $\% 2 \mathrm{C}+$ municipalities\%2C+Slovenia\%2C+Census+2002\&path=../Database/Census2002/Municipalities/ Population/Activity/\&lang=1 (21.11.2010).

Petrović, G. 2001: Dnevne migracije stanovništva opštine Inđija i njihove posledice. Magistarski rad. Geografski fakultet Univerziteta u Beogradu. Beograd.

Renkow, M., Hoower, D. 2000: Commuting, Migration, and Rural-Urban Population Dynamics. Journal of Regional Science 40-2. London.

Social overview 2008. IMAD, 2009. Ljubljana.

Spatial plan of the RS 2010-2014-2021 - Draft 2010 (Prostorni plan Republike Srbije 2010-2014-2021 nacrt). Republička agencija za prostorno planiranje, Ministarstvo životne sredine i prostornog planiranja. Beograd.

Internet 4: http://www.rapp.gov.rs/media/PPRSrbije\%20KARTE/Nacrt_PPRS.pdf (11.3.2010).

Statistical Office of the Republic of Serbia, 2002: Population Census 2002-13: Daily Migrants - Data by Municipalities. Belgrade.

Statistical Office of the Republic of Serbia, 2003: Population Census 2002 - 4: Level of Education and Literacy - Data by Municipalities". Belgrade.

Statistical Office of the Republic of Serbia, 2007: Population Census 2002. Specially Processed Data. Belgrade. Statistical Office of the Republic of Slovenia, 2002:

Internet:http://www.stat.si/popis2002/en/definicije_in_pojasnila_3.html (15.5.2010).

Sun, S. 1980: The possibility and impossibility of intercity commuting. Journal of Urban Economics 23. Amsterdam.

Topole, M., Bole, D., Petek, F., Repolusk, P. 2006: Spatial and functional changes in built-up areas in selected Slovene rural settlements after 1991. Acta geographica Slovenica 46-2. Ljubljana. DOI: 10.3986/AGS46203

Tošić, B., Lukić, V., Ćirković, M. 2009: Settlements of undeveloped areas of Serbia. Zbornik radova Geografskog instituta »Jovan Cvijić« SANU 59-2. Beograd.

Zupančič, J. 2000: Čezmejne delovne migracije (Cross-border daily labour migrations). Geographical Institute. Ljubljana. 


\section{Dnevne migracije - podobnosti in razlike med Srbijo in Slovenijo}

DOI: $10.3986 /$ AGS51205

UDC: 911.37:314.15(497.1:497.4)

COBISS: 1.01

IZVLEČEK: Kot ena od oblik mobilnosti prebivalstva so dnevne migracije kompleksen fenomen prostorske ločenosti kraja dela in kraja prebivanja dela zaposlenega prebivalstva. $\mathrm{V}$ prispevku obravnavamo spremembe v obsegu, smereh in strukturi dnevnih migracijskih tokov v Srbiji ter medsebojno odvisnost med dnevnimi migracijami in drugimi demografskimi in socio-ekonomskimi razvojnimi procesi. Poleg razprave o razlikah med popisno metodologijo v Srbiji in v Sloveniji smo primerjali tudi osnovne značilnosti dnevnih migracij v Srbiji in Sloveniji ter njunih zaposlitveno privlačnih območij.

KLJUČNE BESEDE: geografija, mobilnost, dnevne migracije, delavci, regionalne razlike, suburbanizacija, Srbija, Slovenija

Uredništvo je prejelo prispevek 13.7.2011.

NASLOV:

dr. Vesna Lukić

Inštitut družbenih znanosti

Center za demografska raziskovanja

Kraljice Natalije 45, 11000 Beograd, Srbija

E-mail: vlukic@idn.org.rs

\section{dr. Branka Tošić}

Geografska fakulteta, Univerza v Beogradu Studentski trg 3/III, 11000 Beograd, Srbija

E-mail:brankat@ikomline.net

\section{Vsebina}

$1 \quad$ Uvod

2 Metodologija

3 Značilnosti dnevnih migracij v Srbijistanje, trendi in izzivi

Dnevne migracije - podobnosti in razlike med Srbijo in Slovenijo 333

5 Sklep 335

6 Zahvala 336

7 Literatura 336 


\section{Uvod}

Dnevne migracije prebivalstva predstavljajo tako prebivalstvene kot tudi družbeno-ekonomske in kulturne vezi med območji prebivanja in dela dnevnih migrantov. Imajo veliko različnih vzrokov, pa tudi posledic za obe območji. Ta posebna oblika prostorske mobilnosti prebivalstva je v medsebojni odvisnosti od demografskega, socio-ekonomskega in prometnega razvoja kraja ter razvoja trga dela in trga nepremičnin v naseljih, kjer dnevni migranti bivajo oziroma delajo. Po Boletu lahko govorimo o tipičnem geografskem fenomenu, ki ima vzorčno-posledični odnose z drugimi dejavniki v prostoru (Bole 2004). Kot kazalec vplivnosti in meja funkcionalne privlačnosti naselja so tokovi dnevnih migracij povezani z omejitvami in možnosti mi glede na kraj prebivanja in kraj dela. Sčasoma se osnovni tokovi dnevnih migracij na določenem območju lahko tudi spremenijo. Opredelitev števila dnevnih migrantov (uporabnikov storitev infrastrukturne opremljenosti v kraju dela oziroma t. i. prebivalstva ki ga je treba oskrbeti v kraju bivanja) na primer glede na prebivalstvo, ki živi v določenem kraju, in raziskovanje sprememb v tokovih, obsegu in kvalitativnih značilnostih delavcev - dnevnih migrantov sta pomembna s stališča prometa, infrastrukturne opremljenosti, zaščite okolja ter tudi opredelitve pomembnih demografskih in gospodarskih razvojnih politik.

Pogoj, da bi se dnevne migracije sploh pojavile in razvijale, je heterogenost prebivalstva in družbeno-ekonomskih pogojev v okviru takšne ozemeljske in časovne razdalje, da sta ugodni za potekanje dnevnih migracij. Do medkrajevnih migracij ne bo prišlo, če ne vključimo tudi nekatere heterogene dejavnike (Sun 1980). Čim večje so socio-ekonomske, demografske in druge razlike med začetnem in namembnim območjem dnevnih migracij, pa tudi med prebivalstvom v teh območjih, tem večja je verjetnost, da bo prišlo do dnevnih ali drugih oblik migracij. Kateri od dejavnikov ima prevladujoči vpliv na dnevne migracije, je odvisno tako od značilnosti posameznika kot tudi od značilnosti vsakega posameznega prostora.

\section{Metodologija}

Čeprav je v primerjavi z anketnimi podatki prednost popisnih podatkov za preučevanje dnevnih migracij prebivalstva v velikem obsegu in dejstvu, da niso prikazani samo za določeno lokacijo, pa so rezultati popisa prebivalstva, ki jih objavljajo uradne ustanove v Srbiji, za potrebe znanstvenih raziskavah omejeno uporabni. Objavljeni agregirani podatki o dnevnih migrantih ne omogočajo ocene obsega in smeri gibanja tokov delavcev v določeni administrativno-teritorialni enoti, saj so na voljo zgolj podatki o izhodnih dnevnih migracijskih tokovih na ravni občine. Tako do spoznanj o celotnem funkcionalnem vplivu določenega prostora ni mogoče priti.

Da bi pridobili čim večji obseg informacij o osebnih značilnostih dnevnih migrantov, so v tem prispevku kot vir podatkov za preučevanje dnevnih migracij v Srbiji uporabljeni rezultati posebne obdelave Popisa prebivalcev iz leta 2002 (poudarek v tej obdelavi popisnih podatkov je na posameznih osebah in ne na določenih skupinah prebivalstva). Križane so preglednice po kraju prebivanja in kraju dela dnevnih migrantov skupaj z določenimi demografskimi in socio-ekonomskimi značilnostmi delovnih migrantov različnih skupin prebivalstva. Navzkrižno tabeliranje podatkov o dnevnih migracijah prebivalstva v določeno naselje in iz njega nam je omogočilo, da smo lahko preučevali funkcionalni vpliv posameznih naselij in opredelili funkcionalno območje občin ter njihovih dnevnih urbanih sistemov.

V Srbiji in v Sloveniji je dnevni migrant je definiran kot oseba ki stanuje in dela v različnih naseljih (Republiški urad za statistiko Republike Srbije 2002; Internet 5). Pri popisnih podatkih so razlike v možnostih za preučevanje dnevnih migracij v Srbiji in Sloveniji, ki se nanašajo na dnevne migrante, neposredno povezane s popisnimi vprašanji. Popisni obrazec iz leta 2002 v Republiki Srbiji vsebuje samo vprašanja o pogostosti vrnitve delavcev iz kraja zaposlitve v kraj stalnega prebivanja (možni odgovori so: vsak dan, enkrat na teden, redko). Na podlagi tega vprašanja smo določili skupino dnevnih migrantov. Za razliko od popisnega obrazca iz leta 2002 v Srbiji obsega popisni obrazec iz leta 2002 v Sloveniji več vprašanj, ki omogočajo izločanje skupine prebivalstva, ki dela na domu, kot tudi o vrsti prevoza na delo in času (v minutah), potrebnem za potovanje na delo v eni smeri (Internet 5). V Srbiji bo vprašanje o načinu prevoza na delo dnevnih migrantov v popisnem obrazcu v letu 2011, v skladu s priporočili CES-a (Konferenca evropskih statistikov) za popis prebivalstva, gospodinjstev in stanovanj v letu 2011. To bo omogočilo primerljivost podatkov z drugim državami, med katerimi je tudi Slovenija, čeprav bo Slovenija v letu 2011 izvedla prvič t. i. registrski popis prebivalstva (in ne anketnega). 
$\mathrm{V}$ tem prispevku obravnavamo spremembe $\mathrm{v}$ obsegu, smereh in tokovih dnevnih migracij v Srbiji, vzroke zanje in njihove posledice. Na podlagi medobčinskih dnevnih migracijskih tokov primerjamo osnovne značilnosti dnevnih migracij v Srbiji in Sloveniji (stanje, trendi, izzivi) ter njunih zaposlitveno privlačnih območij.

\section{Značilnosti dnevnih migracij u Srbiji - stanje, trendi in izzivi}

Zaradi zmanjševanja demografskega potenciala - predvsem na podeželju, kjer »... tudi v primeru večje rasti stopnje rodnosti opažamo negativne demografske učinke... (Nikitović in Lukić 2010, 106) - se zmanjšuje obseg migracij na relaciji vas - mesto. Vedno več migracij je na relaciji manjša mestna središča - večja mestna središča, raste pa tudi skupno število dnevnih migrantov. V dnevnih migracijah v Srbiji je v letu 1981 sodelovalo 514.775 delavcev, od tega je bilo $26 \%$ medobčinskih dnevnih migrantov. Podatki za leto 2002 kažejo da je bilo 565.054 dnevnih delovnih migrantov, od tega 194.245 medobčinskih (34\%) (Republiški urad za statistiko Srbije, 2004).

Na obseg in smeri dnevnih migracij delavcev v Srbiji najbolj vplivajo nesorazmerje v gostoti poselitve in številu prebivalcev med regijami, pa tudi izrazita gospodarska in družbena neenakost. Za spremembe v tokovih (smeri in strukturi) dnevnih migracij so pomembne tudi potekajoče gospodarske reforme, proces deindustrializacije in privatizacija velikih podjetij. Preobrazba trga delovne sile v Srbiji je od leta 2001 potekala $\mathrm{v}$ dveh osnovnih smereh: prva je zmanjšanje skupnega števila zaposlenih ob nizki stopnji zapo slenosti prebivalstva, druga pa je visoka večletna stopnja brezposelnosti (Matković in dr. 2010). Naraščanje dnevne mobilnosti delavcev v Srbiji je eden od možnih načinov prilagajanja prebivalstva in reševanja problema brezposelnosti v lokalnem okolju po eni strani, po drugi strani pa ohranjanje dnevnih migracij kot oblike mobilnosti hkrati preprečuje nadaljnje zgoščevanje prebivalstva v mestnih središčih in okoliških primestnih naseljih. »... Na ta način imajo mala mesta kot kraj prebivanja dnevnih migrantov tak priliv dohodkov, kot bi jim ga prinesla manjše podjetje ali trgovina...« (Parr 1987, 225).

Tranzicijski procesi v Srbiji v prvem desetletju 21. stoletja so vplivali na znižanje dohodkov. Povzročile so ga zmanjšane ali povsem odsotne investicije, postopno ekonomsko "propadanje« podjetji in nerešeni lastninsko-pravni odnosi v procesu privatizacije, dotrajana oprema itd. Ti procesi so najbolj prizadeli mestna središča, v katerih je bila industrija prevladujoči sektor zaposlitve (npr. proizvodnja prometnih vozil, tekstilna in kovinska industrija). Tako so se posamezne občine - nekdanji »industrijski velikani« zaradi znatnega padca dohodka znašle v skupini nerazvitih občin (Tošić in ostali 2009; Miletić in ostali 2009). Veliko število odpuščenih delavcev je znatno povečalo delež brezposelnih v prvem desetletju 21. stoletja, ki je povprečno naraščal po letni stopnji 1,6\%, z visokim deležem dolgoročno brezposelnih, mladih in nekvalificiranih oseb.

Obseg dnevnih migracij je povezan z omejitvami in možnostmi v zvezi s krajem prebivanja in krajem dela, tj. stanjem na trgu delovne sile in trgu nepremičnin. Pereče gospodarske razmere v nerazvitih območjih so vplivale na rast števila dnevnih migrantov. Večina občin v Srbiji, ki so kraj bivanja (in izhodiščna toč ka) številnih dnevnih migrantov v smeri drugih občin (oziroma kraja dela), imajo večinoma večje število brezposelnih prebivalcev in nizek narodni dohodek. Na dnevne migracijske tokove vplivajo tudi nerealno visoke cene nepremičnin $\mathrm{v}$ večjih mestnih središčih v Srbiji, saj ovirajo migracije, pomembne pa so tudi relativno nizke cene javnega prometa. Raziskave, izvedene v Srbiji, so za mesto Pančevo ( $21 \mathrm{~km}$ seve rovzhodno od Beograda) v pokrajini Vojvodina pokazale, da 93,8\% dnevnih migrantov živi v stanovanjih v družinski lasti (Lukić 2008). To se sklada z ugotovitvami drugih avtorjev (Hanson in Pratt 1998), da se lastniki stanovanj in hiš bolj pogosto odločajo za dnevne migracije kot pa za stalno preselitev v kraj dela.

Ko je govora o trendu dnevnih migracij v Srbiji, opažamo postopno povečanje deleža žensk v zaposle nem prebivalstvu in s tem tudi v strukturi dnevnih migrantov po spolu, vendar kljub tem spremembam med dnevnimi migranti še vedno prevladujejo moški. Zaradi povečanja deleža storitvenega sektorja v struk turi nacionalnega gospodarstva se spreminja tudi struktura zaposlenega prebivalstva po sektorihih zaposlitve. V skladu s tem se tudi postopoma zmanjšuje delež dnevnih migrantov v primarnih in sekundarnih dejavnostih in raste delež dnevnih migrantov, zaposlenih v storitvenih dejavnostih.

Od nadaljnjih sprememb v biološki in socio-ekonomski strukturi delovne sile je odvisen tudi trend poteka delovnih migracij v Srbiji. Boljša prometna povezanost in izboljšanje kakovosti prometne mreže so pomembni vplivni prostorski dejavniki, ki bodo prav tako prispevali k oblikovanju novih smeri dnev - 
nih migracij v Srbiji v prihodnosti, skladno s splošnim trendom povečanja števila delovnih migrantov, ki potujejo na daljših razdaljah. Trend vrnitve prebivalstva $v$ ruralna naselja je najbolj opazen $v$ Angliji in v Združenih državah Amerike, kar vpliva na povečanje števila prebivalcev v teh naseljih. Mnenje je, da se ljudje po lastni volji odločajo za breme dodanega potovanja na delo v zameno za bolj kakovostno življenje na podeželju $v$ primerjavi z življenjem $v$ mestu. $V$ tem primeru življenjski slog prevlada nad gospodarskimi razlogi, saj se s tem največkrat podaljša tudi vsakodnevna pot na delo (Renkow in Hoower 2000). V Srbiji še vedno ni opaznejšega procesa suburbanizacije premožnejših slojev prebivalstva, ki vsakodnevno potujejo na delo v večja mestna središča. Prebivalstvo se še nadaljnje seli v mesta (zaradi večjega števila delovnih mest). Večina migrantov se priseljuje v okoliška primestna naselja zaradi nižjih cen nepremičnin in vsakodnevno potuje na delo v bližnja večja mesta. Zaradi tega na dnevno mobilnost delavcev v Srbiji ne vpliva želja po življenje $\mathrm{v}$ zdravi okolici na podeželju, temveč manjše število delovnih mest $\mathrm{v}$ naseljih prebivanja, kar je v pretežni meri rezultat neenakomernega gospodarskega razvoja in zgoščevanja funkcij v večjih mestnih središčih, skupaj z visoko stopnjo brezposelnosti, nastalo zaradi odpuščanja delavcev pri tranzicijskih procesih v srbskem gospodarstvu.

\section{Dnevne migracije - podobnosti in ravlike med Srbijo in Slovenijo}

Opažanje podrobnosti in razlik je osnovni kognitivni proces (Gertner in Markman 1994). Ko govorimo o procesu dnevnih delovnih migracij, je ena od podobnosti med Srbijo in Slovenijo, da igrajo gospodarski dejavniki pomembno vlogo. V obeh državah je število delovnih mest $\mathrm{v}$ občini močno povezano $s$ številom dnevnih migrantov. Večina ruralnih naselij, ki so jih preučevali Topole in dr., je imela presežek delovno aktivnega prebivalstva $\mathrm{v}$ primerjavi s številom delovnih mest, kar je prispevalo $\mathrm{k}$ večji vključenosti prebivalstva iz teh naselij v dnevnih migracijah (Topole in ostali 2006).

V dnevnih migracijah v Srbiji v letu 2002 je bilo udeleženih 22\% delovno aktivnega prebivalstva, v Sloveniji pa 54\% (Republiški urad za statistiko Srbije, 2002; Internet 3). Čeprav je opazen porast števila dnevnih migrantov ki vsakodnevno potujejo v drugo občino, se v Srbiji dnevne migracije najbolj intenzivno odvijajo v okviru občine, medtem ko so v Sloveniji - zaradi manjše površine občin - najbolj intenzivne medobčinske dnevne migracije.

Slika 1: Delež medobčinskih dnevnih migrantov v izbranih občinah v Srbiji.

Glej angleški del prispevka.

Na sliki 1 so prikazane vse občine v Srbiji, v katerih najmanj ena desetina delavcev (10\%) dnevno potuje na delo v drugo občino v letu 2002 (44 od skupaj 161). Najbolj opazna medobčinska dnevna mobilnost delavcev v letu 2002 je v občinah Sremski Karlovci, Niška Banja in Doljevac, ki mejijo na makro-regio nalna mestna središča (Novi Sad - 299.294 prebivalcev in Niš - 250.518 prebivalcev), ter v beograjskih občinah zunaj mestnega naselja Beograd (Barajevo, Grocka in Sopot). V skupini desetih občin, iz katerih je leta 2002 več kot ena tretjina delavcev dnevno potovala na delo v drugo občino, je bilo v štirih občinah (Grocka, Sremski Karlovci, Doljevac in Merošina) število brezposlenih večje od števila zaposlenega prebivalstva (Lukić 2006).

Slika 2: Delež medobčinskih dnevnih migrantov v občinah v Sloveniji.

Glej angleški del prispevka.

V primerjavi s Srbijo so imele vse občine v Sloveniji, z izjemo mestne občine Ljubljana (glej sliko 2), v letu 2002 več kot $10 \%$ delavcev, ki so dnevno potovali na delo v drugo občino. Medtem ko je v Srbiji v samo desetih občinah (od 161 v letu 2002) več kot 35\% delavcev dnevno potovalo na delo v drugo obči no, jih je bilo takšnih v Sloveniji 152 (od 193 občin v letu 2002) (Internet 2, Internet 3).

V obmejnih občinah Slovenije je, glede na to, da je članica EU, prisoten tudi pojav čezmejnih dnevnih migracij, ki v Srbiji ni tako izrazit. Med vzroki za čezmejne dnevne migracije v Sloveniji so neenakomerno število in struktura delovnih mest v lokalnih skupnostih, večje plačilo za enako delo, zanimanje za delo $\mathrm{v}$ tujini, dodatni zaslužek in povpraševanje po bolje izobraženi delovni sili (Zupančič, 2000). Po nekaterih ocenah je čezmejnih dnevnih delovnih migracij več, kot kažejo uradni statistični podatki (uradno 4.500, neuradno 13.000 dnevnih migrantov) (Social overview 2008). 
Kakovostne razlike v strukturi delovne sile med občinami dela in občinami prebivanja, pa tudi neravnovesje med številom izobraženega prebivalstva oz. njegovi kvalificiranosti in potrebami gospodarstva in družbe, neposredno vplivajo na obseg in tokove dnevnih migracij v Srbiji. Ko je govora o izobrazbeni strukturi, obstaja pozitivna povezava med dnevno mobilnostjo prebivalstva in srednješolsko izobrazbo, medtem ko je v Sloveniji povezava za visoko izobražene delavce negativna (Bole, 2004, 30). Vzrok za ta pojav je lahko zgoščenost dejavnosti v večjih mestnih središčih. Končni rezultati popisa prebivalstva iz leta 2002 v Srbiji, povezani z izobrazbeno strukturo, kažejo, da je med prebivalstvom, starim 15 ali več let, $41,1 \%$ oseb s končano srednjo šolo, $23,9 \%$ s končano osnovno šolo in $11 \% \mathrm{z}$ visoko izobrazbo (Republiški urad za statistiko Srbije, 2003). V strukturi dnevnih delovnih migrantov v Srbiji prevladujejo delavci s srednješolsko izobrazbo (59,8\%), medtem ko je tistih z visokošolsko izobrazbo 13,4\% (Republiški urad za statistiko Srbije, 2007). Dve tretjini teh delovnih migrantov potuje med naselji v okviru meja iste občine. Če pogledamo samo dnevne migrante $\mathrm{z}$ visokošolsko izobrazbo, je velika večina $(83,3 \%$ od skupnega števila dnevnih migrantov $\mathrm{z}$ visokošolsko izobrazbo) vključena v medobčinske dnevne migracije (Lukić in Tošić 2009, 30). V Srbiji ne obstajajo podatki o časovni ali prostorski razsežnosti dnevnih migracij. Če pa upoštevamo, da imajo srbske občine $\mathrm{v}$ povprečju večjo površino $\left(557 \mathrm{~km}^{2}\right)$ in obsegajo v povprečju 34 naselij ter da dve tretjini dnevnih migrantov potuje vsak dan med dvema naseljema v okviru meja iste občine, lahko potrdimo domnevo, da manjše število medobčinskih dnevnih migrantov s pretežno visokošolsko izobrazbo potuje na daljših razdaljah.

Čeprav za Srbijo ne obstajajo popisni podatki o načinu prevoza dnevnih migrantov na delo, rezultati nekaterih anketnih raziskav avtorjev Bjeljac (1992) in Petrović (2001) kažejo, da v Srbiji največje število dnevnih migrantov uporablja javni prevoz, predvsem avtobus. Hkrati pa obstajajo primeri, ko dnevni migranti uporabljajo več prevoznih sredstev. Izbira javnega prevoza kot najbolj pogostega načina potovanja dnevnih migrantov na delo v Srbiji je posledica visokih stroškov prevoza $\mathrm{z}$ lastnim avtomobilom, ki jih večina dnev nih migrantov finančno ne zmore. Nasprotno pa v Sloveniji večina delavcev potuje na delo $\mathrm{z}$ avtomobilom (Gabrovec in Bole 2009).

Za potrebe raziskav o zaposlitveni privlačnosti občin v Srbiji ter primerjavo s Slovenijo (glej Bole 2004) je izbranih 26 regionalnih središč v Srbiji (Beograd, Nišs, Novi Sad, Čačak, Jagodina, Kikinda, Kragujevac, Kraljevo, Kruševac, Leskovac, Loznica, Novi Pazar, Pančevo, Pirot, Požarevac, Šabac, Smederevo, Sombor, Sremska Mitrovica, Subotica, Užice, Valjevo, Vranje, Vršac, Zaječar in Zrenjanin) po predpisani metodologiji. Definirana so v skladu s Prostorskim načrtom Republike Srbije 2010-2014-2021 (Internet 4). Iz te skupine so izključene občine, ki so privlačne za delavce, so pa hkrati znaten vir dnevnih migracijskih tokov delavcev v druge občine, kot tudi občine, ki privlačijo delavce iz manjšega števila občin. Glavno mesto Beograd je zaposlitveno najbolj privlačno, mesto Novi Sad v pokrajini Vojvodina zaseda drugo mesto, medtem ko je mesto Niš tretje največje zaposlitveno središče v Srbiji (glej Preglednico 1).

Preglednica 1: Izbrane občine v Srbiji in privlačnost za zaposlitev

\begin{tabular}{|c|c|c|c|c|c|c|c|}
\hline \multirow[t]{2}{*}{ občine } & \multirow{2}{*}{$\begin{array}{l}\text { število delovnih } \\
\text { mest }\end{array}$} & \multicolumn{6}{|c|}{ število občin (\%), iz katerih prihajajo dnevni migranti, po deležu skupne delovne sile } \\
\hline & & $\operatorname{pod} 1 \%$ & $1-10 \%$ & $10-20 \%$ & $20-40 \%$ & $40-60 \%$ & nad $60 \%$ \\
\hline Beograd & 558739 & 57 & 44 & 6 & 5 & 1 & 7 \\
\hline Kragujevac & 63102 & 46 & 8 & 2 & 1 & 2 & 1 \\
\hline Kruševac & 46954 & 48 & 6 & 2 & 1 & 2 & 2 \\
\hline Niš & 90057 & 43 & 10 & 3 & 2 & 1 & 8 \\
\hline Novi Sad & 122338 & 59 & 23 & 5 & 3 & 3 & 7 \\
\hline Užice & 32139 & 27 & 4 & 3 & 0 & 1 & 2 \\
\hline Subotica & 54514 & 41 & 9 & 1 & 1 & 1 & 1 \\
\hline
\end{tabular}

Vir: Republiški urad za statistiko Srbije, 2007; lastni izračun.

Primerjava zaposlitvene privlačnosti občin v Srbiji in Sloveniji kaže, da sta glavni mesti v obeh državah najbolj privlačni, ker ponujata največje število delovnih mest in najbolj raznolika dela. Velik funkcional ni vpliv glavnega mesta Slovenije Ljubljane je predvsem izrazit na ravni NUTS 2. Od treh funkcionalnih območij nadnacionalne pomembnosti (zahodna, srednja, vzhodna Slovenija) pokriva funkcionalno mestno območje Ljubljane 78\% ozemlja Slovenije (Drobne in dr., 2010, 301). Podobno je tudi v Španiji in Italiji (ter v nekaterih drugih evropskim državah), kjer so najbolj izraziti dnevni migracijski tokovi iz regij, ki 
obkrožajo glavno mesto pokrajine, ali širše okolice proti glavnemu mestu (Artis in ostali 2000; Cristaldi 2005). Podatki o zaposlitveni privlačnosti občin v Srbiji potrjujejo pomembnost mestnih središč na osi Donava-Morava kot glavni razvojni osi Srbije (Nikitović in Lukić 2003). Hkrati lahko ugotovimo, da $\mathrm{v}$ tradicionalno emigracijskem prostoru vzhodne Srbije ne izstopa niti eno večje zaposlitveno središče, ki bi imelo bolj izraženo privlačno moč za zaposlitev dnevnih migrantov.

Razmerje med številom delovnih mest in številom zaposlenih v občini, vključno s samozaposlenimi, pokaže presežek ali pomanjkanje delovnih mest v občini. Če je število delovnih mest v občini najmanj $16 \%$ večje od števila prebivalstva v tej občini, potem je občina izrazito delovno usmerjena (glej Internet 1). Večina občin v Srbiji je bila v letu 2002 v skupini »izrazito bivalne občine«. Med »izrazito delovnimi« občinami so bile nekatere beograjske občine ter makro-regionalna mestna središča Kragujevac, Novi Sad in Niš. Ne gre pozabiti, da se te skupine lahko spreminjajo glede na spremembe socio-ekonomskih pogojev v občinah prebivanja in v občinah dela dnevnih migrantov. Takšen primer so občine Koper, Nova Gorica in Kranj v Sloveniji, ki so v letu 2005 sodile med »izrazito delovne« občine, a so bile že leta 2006 preuvrščene v skupino "zmerno delovnih« občin (Internet 1).

Preglednica 2: Dnevni migracijski indeks na ravni občin v Srbiji (2002) in Sloveniji (2006).

\begin{tabular}{lcccr}
\hline & število občin v Srbiji & $\%$ & število občin v Sloveniji & $\%$ \\
\hline izrazito bivalne & 66 & 40,9 & 37 & 19,2 \\
pretežno bivalne & 23 & 14,3 & 43 & 22,2 \\
zmerno bivalne & 17 & 10,5 & 48 & 24,9 \\
šibko bivalne & 6 & 3,7 & 32 & 16,6 \\
zmerno delovne & 13 & 8,1 & 13 & 10,4 \\
izrazito delovne & 36 & 22,4 & 6,7 \\
skupaj & 161 & 100 & 193 & 100 \\
\hline
\end{tabular}

Vir: Republiški urad za statistiko Srbije, 2007; Internet 1; lastni izračun.

Če primerjamo podatke o vrednosti dnevnega migracijskega indeksa (v Sloveniji je po letu 2007 naziv spremenjen $\mathrm{v}$ indeks delovne migracije), lahko ugotovimo, da je večina občin v Srbiji med »izrazito bivalnimi« občinami, medtem ko je v Sloveniji večina občin v skupini »zmerno bivalnih«. Pripominjamo, da rezultati niso v celoti primerljivi zaradi različnih časovnih obdobij, iz katerih so podatki prevzeti.

Povprečen slovenski dnevni delovni migrant je moški, s srednješolsko izobrazbo, prebiva od 15 do 30 minut od kraja dela in na delo v drugo občino potuje sam v avtomobilu (Bole 2004; Bole 2010; Kozina 2010; Internet 1). Povprečen srbski delovni migrant je prav tako moški s srednješolsko izobrazbo, ki na delo potuje $\mathrm{z}$ avtobusom $\mathrm{v}$ okviru meja iste občine, $\mathrm{v}$ kateri prebiva.

\section{Sklep}

Številne posledice dnevnih migracij delavcev zahtevajo neprekinjeno sledenje in raziskovanje sprememb obsega in smeri tokov dnevnih delovnih migracij ter kvalitativnih značilnosti dnevnih delovnih migrantov, kot tudi determinant teh sprememb. Vsakodnevno potovanje dela prebivalstva iz enega naselja v drugo pozitivno učinkuje na zmanjšanje potreb po vlaganjih v komunalno in stanovanjsko infrastrukturo v kraju dela (večinoma so to mesta). Po drugi strani pa lahko preobremenjena prometna infrastruktura v smereh, $\mathrm{v}$ katerih potekajo dnevne delovne migracije, povzroči zahteve po pogostem in nenačrtnem večjem vlaganju v prometno mrežo in vozni park javnega prevoza.

Značilnosti dnevne mobilnosti delavcev se razlikujejo glede na lastnosti območja, v katerem se dogajajo. Preučevanje zaposlitvene privlačnosti občin ter izračunane vrednosti dnevnega migracijskega indeksa $\mathrm{v}$ Srbiji in v Sloveniji kažejo, da imata glavni mesti $\mathrm{v}$ obeh državah daleč največjo zaposlitveno privlačnost. V Srbiji je bolj izražena prevladujoča funkcionalna privlačnost glavnega mesta Beograda v primerjavi $\mathrm{z}$ drugimi mestnimi središči zaradi neenakomernega regionalnega razvoja ter zgoščenosti prebivalstva in funkcij v manjšem številu večjih mestnih središč.

Prevladujoči tokovi dnevnih migracij, strukturne značilnosti in način prevoza dnevnih delovnih migrantov v Srbiji in Sloveniji so si do določene mere med seboj podobni. Razlike v dnevni mobilnosti prebivalstva Slovenije in Srbije so povezane z različno velikostjo držav, specifično mrežo naselij (večje število manjših 
naselij v Sloveniji), značilnostmi in kakovostjo prometne mreže, ter z višjo ravnjo skupne razvitosti države in življenjskega standarda v Sloveniji v primerjavi z Srbijo. V Sloveniji dnevni migranti v večji meri dnevno potujejo na delo z avtomobilom zunaj meja svoje občine prebivanja, pri čemer moramo upoštevati, da so občine $\mathrm{v}$ Sloveniji manjše kot $\mathrm{v}$ Srbiji. Za nadaljnje raziskave bi bilo zanimivo preučiti in primerjati tudi druge značilnosti dnevnih migrantov $\mathrm{v}$ teh dveh in v sosednjih državah ter njihove spremembe $\mathrm{v}$ času in prostoru. K temu bodo vsekakor pripomogla dodatna vprašanja, povezana $z$ dnevnimi migranti, ki so že načrtovana v naslednjem popisu prebivalcev v Srbiji v letu 2011.

\section{Zahvala}

Raziskava je nastala v okviru projekta, ki ga je financiralo Ministrstvo za izobraževanje in znanost Republike Srbije (št. 47006).

\section{Literatura}

Glej angleški del prispevka. 